\title{
Comparison of sea surface microlayer and subsurface water bacterial communities in the Baltic Sea
}

\author{
Anna Lindroos ${ }^{1, *}$, Hilda Marta Szabo ${ }^{2}$, Mikko Nikinmaa ${ }^{1}$, Piia Leskinen ${ }^{1}$ \\ ${ }^{1}$ Division of Genetics and Physiology, Department of Biology, University of Turku, 20014 Turku, Finland \\ ${ }^{2}$ Department of Chemistry and Bioengineering, Environmental Engineering and Biotechnology, \\ Tampere University of Technology, 33101 Tampere, Finland
}

\begin{abstract}
Sea surface microlayer (SML) and underlying subsurface water (SSW) bacterial communities from the Baltic Sea were studied using culturing, flow cytometry and terminal restriction fragment length polymorphism (T-RFLP). Dissolved organic matter (DOM) of water samples was determined using high performance liquid size-exclusion chromatography and by measuring dissolved organic carbon. Cadmium, copper, lead and mercury were also measured from the water samples. Two methods were compared for SML sampling: metal screen (MS) and polycarbonate membranes (PCM). All sampling sites were located in the Archipelago Sea off the southwest coast of Finland. The hypothesis was that because of its unique features, such as accumulation of nutrients and pollutants and being unshaded from UV-radiation, the SML would support a different bacterial community to that of SSW. T-RFLP profiles showed differences between the bacterial community compositions of SML and SSW at most sampling sites. In addition, temporal and sampling-site-dependent differences were observed. There were no significant differences in DOM in SML and SSW samples. In most cases, the number of bacteria was slightly higher in the SML than in SSW. No significant cytotoxicity was observed in any of the water samples. Since no temporal trends were obvious, our results suggest that, although bacterial communities in the SML Archipelago Sea differ to some extent from the ones living in SSW, SML is a dynamic environment where bacterial communities possibly develop originally from bacterioplankton and change over time.
\end{abstract}

KEY WORDS: Sea surface microlayer - Bacterial community structure - T-RFLP - Dissolved organic matter Resale or republication not permitted without written consent of the publisher

\section{INTRODUCTION}

The sea surface microlayer (SML) is considered to be within the $1 \mathrm{~mm}$ upper layer of the sea (Liss \& Duce 1997). It differs from the subsurface water in many physical and chemical properties (Hardy 1982). It has been suggested that the presence of strong environmental pressure, such as pollutants and strong unshaded UV radiation, leads to the development of specific bacterial communities at the air-water interface (Norkrans 1980, Hermansson et al. 1987). However, the accumulation of nutrients is an advantage in this environment (Maki 2003). Bacteria living in the
SML are called bacterioneuston (Naumann 1917), in comparison to bacterioplankton, which are bacteria inhabiting the subsurface water (SSW). Recent studies (Agogué et al. 2005, Franklin et al. 2005, Cunliffe \& Murrell 2009, Stolle et al. 2010, Cunliffe et al. 2011) have increased the general understanding of the properties and function of the SML. However, the significance and role of the SML are still not well understood.

Several studies reporting bacterial numbers, activity and community structure, as well as other characteristics of the SML, have been published in recent years. Some groups have reported slightly higher 
numbers of microorganisms in SML than in SSW (Kuznetsova et al. 2004, Joux et al. 2006), while others have found even 100-fold enrichment of bacteria in the SML (Bezdek \& Carlucci 1972, Hardy 1982). On the other hand, lower numbers and cases with no significant difference have also been observed (Bell \& Albright 1982, Joux et al. 2006). Results on bacterial community structure are equally variable. Franklin et al. (2005) studied the differences in bacterial communities in the North Sea. Their results showed significantly lower bacterial diversity in the SML than in the SSW. Cunliffe et al. (2009b) observed that bacterioneuston communities differed from the ones in bacterioplankton in a mesocosm experiment. The difference, however, depended on sampling method and time. Results from an estuarine area in Portugal suggested that SML communities originate from underlying waters and that the tides have an effect on the comparison of bacterioneuston and bacterioplankton community dynamics (Santos et al. 2009).

The thickness of the SML sampled depends on the sampling method. There have been studies comparing different sampling methods of SML (Agogué et al. 2004, Cunliffe et al. 2009a, Stolle et al. 2009), which is a challenging target to sample because it can easily get mixed with the subsurface water. Stolle et al. (2009) found that different sampling devices affected the bacterial activity measures, but they did not affect the bacterial counts or community composition. Our choice of sampler was based on research done by Agogué et al. (2004) in the Mediterranean Sea near the French and Spanish coasts. They used a metal screen sampler (Garrett 1965) for the sampling of the SML. The metal screen samples approximately the upper $440 \mu \mathrm{m}$ layer of the sea surface (Daumas et al. 1976), and it has been claimed that the thickness of the sampled layer dilutes the SML community with the subsurface water (Cunliffe et al. 2009a). However, the metal screen allows the collection of a water sample that can be analyzed using various methods; whereas, for example, polycarbonate membranes can only be used for the sampling of bacteria for DNA-based analyses.

The Baltic Sea is one of the largest brackish waters in the world. It differs from the oceans in many features. The average depth is only $50 \mathrm{~m}$ and the salinity of the Baltic Sea ranges from 1 to $3 \%$ in the northern and eastern parts to $\sim 10 \%$ in the south near the Danish inlet. The Archipelago Sea in SW Finland has numerous small islands and is only $23 \mathrm{~m}$ deep on average. Because of the salinity gradients, bacterial communities of the Baltic are influenced by freshwater bacterial species, especially in the northern areas of the Baltic and near river outflows (Vaatanen 1982, Holmfeldt et al. 2009). Bacteriological variables of the Baltic Sea have been measured in general; for example, horizontal and vertical comparison of the bacterial counts and type (Vaatanen 1980, Gast \& Gocke 1988, Koskinen et al. 2011) and bacterial production (Heinanen 1991, Dahlgren et al. 2010) have been studied. However, there has been very little previous research on bacteria inhabiting the SML of the Baltic Sea.

Stolle et al. (2009) found no evidence of distinct bacterial communities, when they studied the activity and structure of the bacterioneuston in 2 locations: one in the southern Baltic and one in the central Baltic. In their later study Stolle et al. (2010) reported differences between particle-attached neustonic and planktonic bacteria, while only small differences were observed in the free-living fraction of bacteria. In addition, the influence of wind conditions on the SML bacterial communities was studied in the southern Baltic (Stolle et al. 2010). In comparison to the study of Stolle et al. (2010), our sampling sites were located in a quite shallow archipelago with numerous small islands. The samplings were performed in sheltered harbour bays where wind conditions are calmer, and thus the mixing of water is decreased compared to the open sea.

The aim of the present study was to investigate whether there are differences in bacterial communities between SML and SSW collected from the Archipelago Sea, SW Finland. Both the number of bacteria and community structure were compared. In addition, the presence of some metals (cadmium, copper, lead and mercury) and the quality and quantity of dissolved organic matter (DOM) were measured, because both pollutants and DOM can affect the composition of a bacterial community. Harbours of different sizes and an undisturbed bay were chosen for comparison. Bacterial community profiles were studied using terminal restriction fragment length polymorphism (T-RFLP), which is a commonly used method enabling a rapid comparison of bacterial communities (Avaniss-Aghajani et al. 1994, Liu et al. 1997).

\section{MATERIALS AND METHODS}

\section{Sampling}

Samples were collected in May, June and July 2007 and June-July 2008. Sampling sites were located in the Finnish Archipelago in harbour bays of Nauvo 


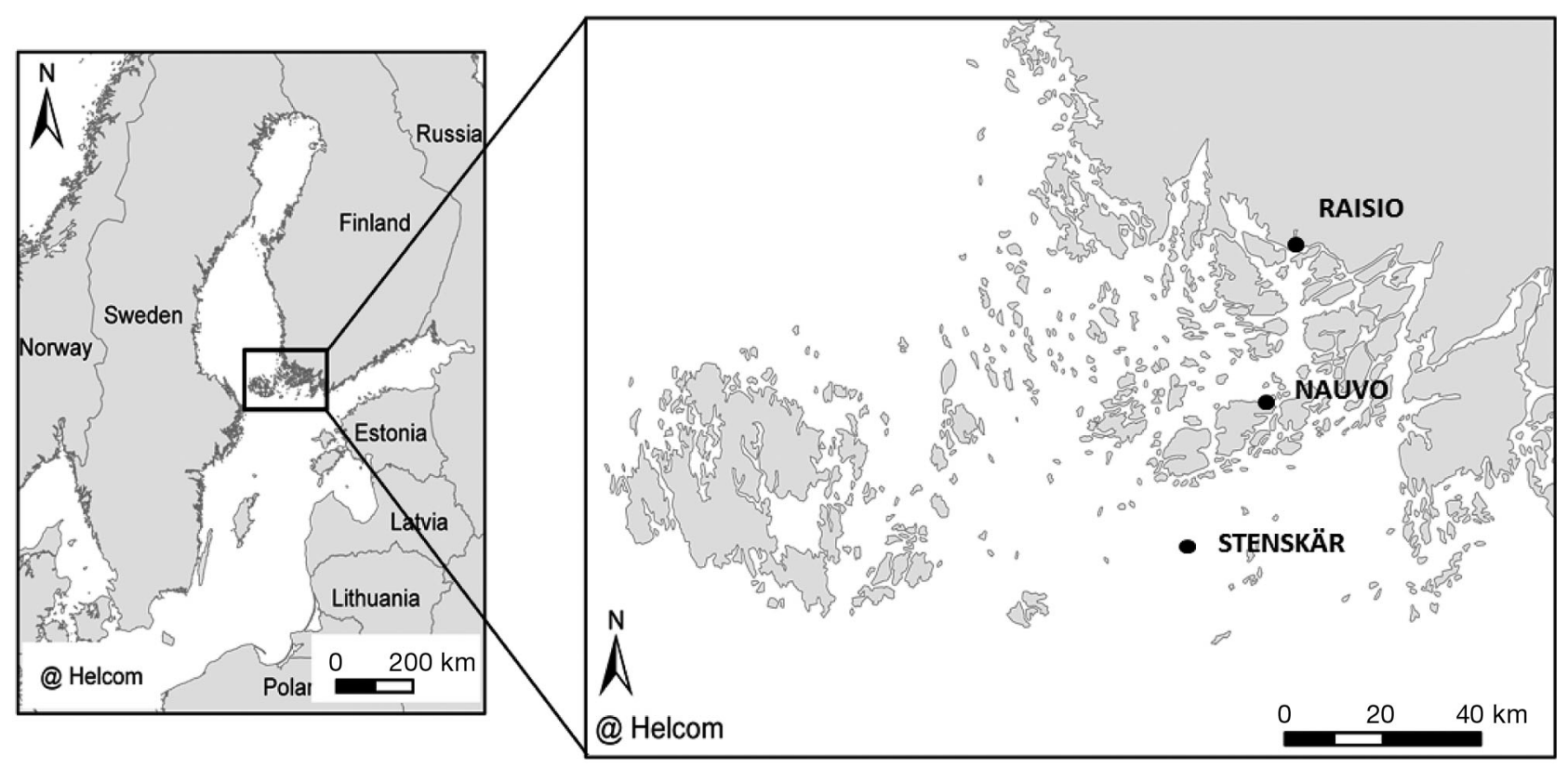

Fig. 1. Sampling sites in the Archipelago Sea of SW Finland. Samples were collected in May, June and July 2007 and June-July 2008. Sampling sites were located in the Archipelago Sea in harbour bays of Nauvo (N) $\left(60^{\circ} 11^{\prime} \mathrm{N}, 2^{\circ} 54^{\prime} \mathrm{E}\right)$, Stenskär (H) $\left(60^{\circ} 4^{\prime} \mathrm{N}, 22^{\circ} 3^{\prime} \mathrm{E}\right)$ and Raisio (R) $\left(60^{\circ} 27^{\prime} \mathrm{N}, 22^{\circ} 7^{\prime} \mathrm{E}\right)$, and in the undisturbed bay in Stenskär (C) $\left(60^{\circ} 4^{\prime} \mathrm{N}, 2^{\circ} 3^{\prime} \mathrm{E}\right)$

$(\mathrm{N})$, Stenskär $(\mathrm{H})$ and Raisio $(\mathrm{R})$, and in the undisturbed bay in Stenskär (C) (Fig. 1). Site R is located close to the mainland, near a river inlet, whereas the other 3 sampling sites are located fairly close to each other and further out in the archipelago. $\mathrm{R}$ is a busy harbour with place for 700 boats; $\mathrm{N}$ is a medium sized harbour with place for 120 boats; and $\mathrm{S}$ is a small harbour with place for 15 boats. SML samples were collected using a Garrett metal screen (MS) (Garrett 1965) and samples obtained from several dips of the MS were pooled. The MS measures were similar to those described in Agogué et al. (2004). SSW samples from $\sim 40 \mathrm{~cm}$ depth were taken with a sterile bottle. The sampling depth of the SML was estimated to be $\sim 40 \mu \mathrm{m}$. Sampling days were chosen based on the weather conditions (Table 1), to avoid interference by hard wind or rain. Samples were kept on ice in a cooler box until further processing in the laboratory within $8 \mathrm{~h}$ of collection.

Additional SML and SSW samples were collected to assess the effect of the sampling technique in October 2009 from sampling site R, using both MS and a polycarbonate membrane (Cunliffe et al. 2009a). In the polycarbonate sampling method, the membrane is placed on the SML for $10 \mathrm{~s}$ using sterile forceps. SSW samples were taken both with a glass bottle and by placing a polycarbonate membrane into a small plastic bag, which was then opened under water. Af-
Table 1. Weather conditions during sampling at the 4 different sampling sites (see Fig. 1) in the summers of 2007 and 2008. Table shows wind, visible slicks on the surface (X: slicks present), cloudiness and water temperature. Sampling days were chosen based on the wind conditions. Cloudiness varies from sunny (0) to cloudy (4)

\begin{tabular}{|llcccc|}
\hline Site & Date & $\begin{array}{c}\text { Wind } \\
\left(\mathrm{m} \mathrm{s}^{-1}\right)\end{array}$ & $\begin{array}{c}\text { Visible } \\
\text { slicks }\end{array}$ & $\begin{array}{c}\text { Cloudi- } \\
\text { ness }(0-4)\end{array}$ & $\begin{array}{c}\text { Water } \\
\text { temp. }\left({ }^{\circ} \mathrm{C}\right)\end{array}$ \\
\hline C & May 31, 2007 & 1 & & 0 & 12 \\
$\mathrm{C}$ & June 14, 2007 & $0-3$ & & 4 & 15 \\
$\mathrm{C}$ & June 26, 2007 & 3 & & 3 & 16 \\
$\mathrm{C}$ & July 3, 2008 & $2-3$ & & 1 & 16 \\
$\mathrm{C}$ & July 9, 2008 & 3 & & 2 & 17 \\
$\mathrm{H}$ & May 31, 2007 & 1 & & 0 & 13 \\
$\mathrm{H}$ & June 14, 2007 & $1-3$ & & 4 & 15 \\
$\mathrm{H}$ & June 26, 2007 & $0-2$ & & 3 & 16.5 \\
$\mathrm{H}$ & July 3, 2008 & $3-4$ & & $1-2$ & 16 \\
$\mathrm{H}$ & July 9, 2008 & $2-3$ & & 1 & 17 \\
$\mathrm{~N}$ & May 31, 2007 & $0-3$ & $\mathrm{X}$ & 1 & 17 \\
$\mathrm{~N}$ & June 14, 2007 & $1-2$ & & 4 & 16 \\
$\mathrm{~N}$ & June 26, 2007 & $1-2$ & & $2-3$ & 16 \\
$\mathrm{~N}$ & July 3, 2008 & 1 & & 3 & 17 \\
$\mathrm{~N}$ & July 9, 2008 & $1-2$ & & 0 & 18 \\
$\mathrm{R}$ & May 31, 2007 & 5 & & 3 & 14 \\
$\mathrm{R}$ & June 14, 2007 & $1-3$ & $\mathrm{X}$ & 3 & 17 \\
$\mathrm{R}$ & June 26, 2007 & 2 & & 2 & 20 \\
$\mathrm{R}$ & July 3, 2008 & $3-4$ & & $2-3$ & 17 \\
$\mathrm{R}$ & July 9, 2008 & 1 & $\mathrm{X}$ & 3 & 16 \\
& & & & & \\
\hline
\end{tabular}


ter closing the plastic bag, it was lifted from the water and the membrane was removed after $10 \mathrm{~s}$ and placed into a sterile Eppendorf tube. Non-filtered water was taken for enumeration of culturable bacteria and the rest of the water was pre-filtered through $11 \mu \mathrm{m}$ pore size filter papers (MN 615 185; MachereyNagel) and then $6 \mu \mathrm{m}$ pore size filter papers (Whatman; Schleicher \& Schuell), leaving mainly the nonparticle-attached fraction of bacteria for analysis. For the comparison of sampling methods, water was not pre-filtered, so both free-living and particle-attached bacteria were included in the analysis.

\section{Enumeration of culturable bacteria}

Enumeration of culturable bacteria was conducted with samples collected in summer 2007 (first 3 time points). A quantity of $100 \mu \mathrm{l}$ of $10^{-1}$ and $10^{-2}$ diluted (in $0.5 \% \mathrm{NaCl}_{2}$ ) non-filtered seawater samples were plated on marine agar 2216 (Difco) and incubated at room temperature for $6 \mathrm{~d}$. Afterwards, colony forming units (CFUs) were counted.

\section{Enumeration of total bacteria}

Total number of bacteria was counted with a flow cytometer for samples collected in summer 2007. Three parallel pre-filtered samples were fixed with $2 \%$ paraformaldehyde in cryotubes and left at room temperature for 5 to $10 \mathrm{~min}$. After fixing the cells, samples were frozen in liquid nitrogen and stored at $-80^{\circ} \mathrm{C}$ until analysis. Before the flow cytometer analysis, the samples were stained with $0.01 \%$ nucleic acid dye SYBR-Green (Fluka). Before counting the bacteria, the samples were kept in the dark for at least $15 \mathrm{~min}$ at room temperature. The total number of bacteria was analyzed according to green fluorescence (fluorescin isothiocyanate, FITC) using a BD LSR II flow cytometer (Becton-Dickinson).

\section{Molecular analysis of the samples}

For DNA extraction, 100 to $300 \mathrm{ml}$ of pre-filtered water was filtered on $47 \mathrm{~mm}$ diameter, $0.22 \mu \mathrm{m}$ pore size polycarbonate filters (GE Water \& Process Technologies), with the volume depending on the amount of organic matter still remaining in the sample after pre-filtration. Three parallel filtrations were done for each sample. Filters were stored at $-80^{\circ} \mathrm{C}$ until DNA extraction.
DNA extraction was carried out as described by Ghiglione et al. (2005). For T-RFLP analysis partial 16S rDNA was amplified by PCR using bacterial 16S primers 27F_FAM (AGA GTT TGA TCC TGG CTC AG) (Pandey et al. 2007, Smalla et al. 2007) and 926R_HEX (CCG TCA ATT CCT TTG AGT) (Pandey et al. 2007). The reaction mixture consisted of $1 \mu$ l of non-diluted, half-diluted or $10^{-1}$ diluted template DNA, $25 \mathrm{mM}$ dNTPs, $10 \mu \mathrm{M}$ of each primer, $10 \times$ buffer and 0.5 units of KAPA Taq polymerase (KAPA Biosystems) for $25 \mu$ reaction. The amount of PCR products was estimated in a $1 \%$ agarose gel and then purified with a PCR purification kit (Macherey-Nagel). Restriction of purified PCR products was done with HhaI and RsaI restriction enzymes separately. After a restriction time of $6 \mathrm{~h}$, products were precipitated in ethanol solution (the final mixture containing $10^{-1}$ volumes of $3 \mathrm{M}$ sodiumacetate (NaOAC) and 2 volumes of $97 \%$ ethanol) for $1 \mathrm{~h}$ at $-70^{\circ} \mathrm{C}$. Then, samples were centrifuged in a microcentrifuge for $30 \mathrm{~min}$ at $12000 \times g$, and supernatants were carefully removed. Pellets were washed with $500 \mu \mathrm{l} 70 \%$ ethanol and centrifuged for $10 \mathrm{~min}$ at $12000 \times g$. Finally, samples were left to airdry in a laminar hood and re-suspended in $10 \mu \mathrm{l}$ of sterile water. For the T-RFLP run with an ABI analyzer, 2 to $6 \mu$ of sample ( 50 ng of DNA) was mixed with 6 to $10 \mu \mathrm{l}$ of Hi-Di (Applied Biosystems) solution and $0.01 \mu \mathrm{l}$ of size-standard 600LIZ (Applied Biosystems). The fluorescent peak profiles were analyzed with Peak Scanner software (Applied Biosystems), and the peak data was processed and the peak profiles constructed using T-REX (Culman et al. 2009), a web-based open access program. The T-REX uses the approach of Abdo et al. (2006) for noise filtering and the method of Smith et al. (2005) for the peak alignment. The default values of the program were used for noise filtering; peak alignment was done using a clustering threshold of 0.6; data from replicate analyses of the same sample were averaged; and relative peak heights were used for constructing the peak profiles. The community profiles were clustered based on the Bray-Curtis similarity matrix of $\log (x+1)$ transformed data using PRIMER-6 (version 6.1.12, Primer-E).

\section{Metal measurements}

The presence of metals (cadmium, copper, lead and mercury) in the water samples was tested using different whole-cell bacterial reporters, each expressing bacterial luciferase (lux) under the control of regula- 
tory elements induced by a certain metal. The following bacterial strains were used: Staphylococcus aureus RN4220 (pTOO24) for cadmium, Bacillus subtilis BR151 (pTOO24) for lead, Escherichia coli MC1061 (pmerRBSBPmerlux) for mercury and E. coli MC1061 (pSLcueR/pDNPcopAlux) for copper. The strains $E$. coli MC1061 (pDNlux) and B. subtilis BR151 (pTOO24), which have constitutive expression of luciferase, were used for the detection of non-specific cytotoxicity. The sensor strains and their use, including the detection limits for each strain have been described earlier (Tauriainen et al. 1998, Ivask et al. 2009). Briefly, freeze-dried bacteria were rehydrated in heavy metal MOPS (3- $N$-morpholinopropane sulfonic acid) (HMM) (LaRossa et al. 1995) Luria-Bertoni (LB) medium. Then $50 \mu \mathrm{l}$ of bacterial suspension and $50 \mu \mathrm{l}$ of water samples (standard dilutions) were pipetted on a 96-well plate. The plates were incubated for 1 to $2 \mathrm{~h}$ at 30 to $37^{\circ} \mathrm{C}$ depending on the strain, and luminescence was then measured using a Luminoscan plate reader (Labsystems).

\section{Analysis of DOM of the samples}

The dissolved organic carbon (DOC) of the samples was determined with a TOC-analyzer, SHIMADZU TOC-5000. Additionally, the DOM of the water samples was characterized by high performance liquid size-exclusion chromatography (HPLCSEC). Through HPLC-SEC, the fractionation of the different components of DOM takes place according to their molecular weight, so that the highest molecular weight compounds are eluted earlier than the lowest ones. We applied the method as described earlier by Stedmon et al. (2007), with the modification that we used a diode array UV detector in tandem with a fluorescence detector. The samples for both DOC and HPLC-SEC analysis were first filtered through a $0.45 \mu \mathrm{m}$ polypropylene filter (Whatman); first, $\sim 1 \mathrm{ml}$ of seawater sample was filtered directly into 2 separate vials for chromatography; then up to $5 \mathrm{ml}$ of sample was filtered with the same filter directly into the vials for the TOC-analyzer. The filter was prewashed with $100 \mathrm{ml}$ of deionized water. Fractionation was performed using a Hewlett-Packard HPLC 1100 system with a TSKgel G3000SW $7.5 \mathrm{~mm} \times 30 \mathrm{~cm}$ column. The UV detection wavelength was set to $254 \mathrm{~nm}$, which is commonly used for the detection of humic compounds. The fluorescence detector was set to detect proteintype compounds of the fractions by using tryptophan-like and tyrosine-like fluorescence detection at excitation/emission wavelengths of $270 \mathrm{~nm} /$ $355 \mathrm{~nm}$ and $270 \mathrm{~nm} / 310 \mathrm{~nm}$, respectively. A total of $10 \mu \mathrm{M}$ sodium acetate was used as an eluent at a flow rate of $1 \mathrm{ml} \mathrm{min}{ }^{-1}$ with an injection volume of $30 \mu \mathrm{l}$. Peak area was used for quantitative characterization of DOM, with higher peak area representing a higher amount of corresponding organic fraction. The chromatograms were integrated using ChemStation software (Hewlett Packard, Agilent Technologies). Duplicate samples were run through the system. For the qualitative characterization of organic fractions separated by size-exclusion, the HPLC-SEC column was calibrated with $\mathrm{Na}$-salts of polystyrene sulfonates (PSS), of molecular weight 210, 4300, 6800, $13000 \mathrm{Da}$ (Fluka) and 2200, $3600 \mathrm{Da}$ (Polymer Standard Services). The void volume and permeation volume were determined with Blue Dextrane (1000000 Da) and acetone (58 Da). The obtained calibration equation $(\log \mathrm{MW}=5.4375-$ $0.301 R t$; where $R t$ is the retention time equal to the volume of elution and MW is the molecular weight) served to determine the apparent molecular weights of the eluted fractions.

\section{Statistical analysis of data}

To assess whether there are significant differences between the organic parameters such as DOC, high molecular weight (HMW), and low molecular weight (LMW) fractions of SML and SSW samples, a 1-way ANOVA was performed. To compare SML and SSW at the same site, an independent $t$-test was used. The relation between the organic parameters and bacterial counts was assessed by the Pearson correlation coefficient $r$. Statistical analysis was performed with the statistical program SPSS 15.0 (IBM).

\section{RESULTS}

\section{Comparison of bacterial numbers in SML and SSW samples}

Culturable and total bacteria were counted from the SML and SSW samples collected from the Archipelago Sea to study the differences between SML and SSW. The number of culturable bacteria, determined as on marine agar plates, was generally slightly higher in SML samples than in SSW samples. The only exception was sampling site R on June 26, 2007 (Fig. 2). However, statistically significant differences $(p<0.05)$ between SML and SSW were 


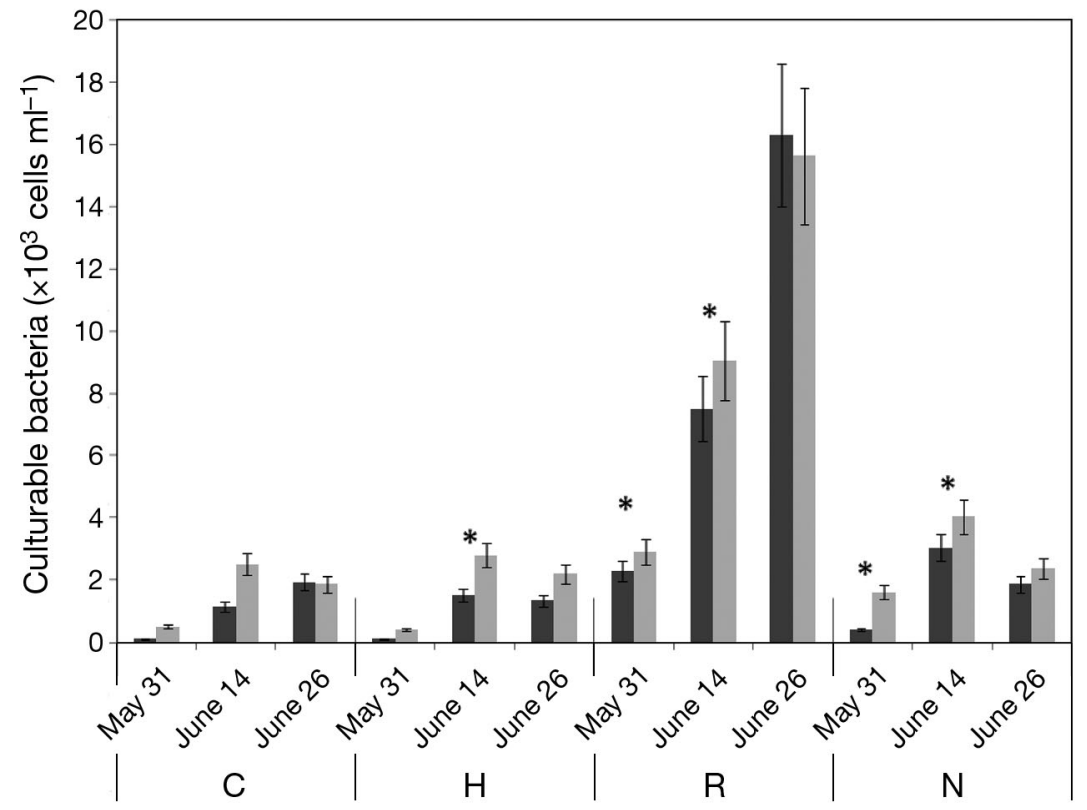

Fig. 2. Number of bacteria growing on marine agar plates in 2007 seawater samples. Surface microlayer (SML; grey bars) and subsurface-water (SSW; black bars) bacterial counts $\left(\mathrm{CFU} \mathrm{ml} \mathrm{m}^{-1}\right)$ from 4 different sampling sites (C, H, R and $N_{i}$ see Fig. 1) and 3 different time points. Figure shows results after $6 \mathrm{~d}$ incubation. Averages of 3 replicates with error bars indicating the maximum and minimum values. ${ }^{*}$ Statistically significant $(\mathrm{p}<0.05)$ differences between SML and SSW similarities between profiles, revealed no systematic difference between the SML and SSW communities of the same sampling site (Fig. 4). Three samples (SML R on July 9; SSW C and $\mathrm{N}$ on July 9) were discarded because the quality of DNA extracted from these samples was low, and, consequently they produced profiles that had low similarity to other samples.

The highest similarities between SML and corresponding SSW were observed at sampling site $\mathrm{N}$ on June 26, 2007 and site R on July 3, 2008 (Fig. 4). Differences in community profiles between SML and SSW were found at most of the sampling sites, but no continuous trend was observed. Because of the high number of peaks in each profile (due to 2 fluorescent primers) and because we used peak heights for calculation of results, the maximum similarities between any samples were restricted to $87 \%$. Based on this, we considered that sample profiles having $>70 \%$ similarity repre- observed only in some of the water samples (Fig. 2).

The bacterial counts on agar plates represented only $\sim 2 \%$ of the total bacteria. The number of total bacteria was higher in most of the SML samples than in corresponding SSW samples; however, the difference was small. Statistically significant differences $(\mathrm{p}<0.05)$ between the SML and SSW were found in the first 2 sampling time points (Fig. 3). Overall, our results indicate that the number of total and culturable bacteria is slightly higher in SML than in the water column just below it.

\section{Bacterial community structure}

For each sample, we obtained 2 separate profiles, both of which included terminal fragments from both ends of the amplicon. The hierarchical clustering analysis, based on Bray-Curtis



Fig. 3. The total number of bacterial cells in 2007 seawater samples as determined by flow cytometer analysis. Surface-microlayer (SML; grey bars) and subsurface-water (SSW; black bars) samples from each sampling site $(C, H, R$ and $\mathrm{N}_{\text {; }}$ see Fig. 1) were compared. Figure shows averages of 3 replicates with error bars indicating the maximum and minimum values. ${ }^{*}$ Statistically significant $(\mathrm{p}<0.05)$ differences between SML and SSW 
sented similar communities. Using this threshold, $\sim 50 \%$ of the SML and SSW sampling pairs compared were considered to represent diverging communities. The peak heights reflect the relative amounts of different species in the sample and thus give more information on the bacterial community structure than presence/absence data. However, they add to the total complexity of the community profiles, thus reducing the similarity between samples.

In general, more similarity was observed between bacterial community profiles in sampling sites, for example $\mathrm{C}$ and $\mathrm{H}$ (Fig. 4, cluster a), than between the SML and the SSW of the same site. Most of the R samples formed a completely separate cluster (Fig. 4, cluster b). Apart from a few individual samples, the community profiles constructed with both HhaI and RsaI clustered in a similar manner, which suggests that the clusters are based on real differences between communities and not merely on random differences produced by the method.

\section{Comparison of samples obtained with polycarbonate membranes and metal screen}

To ensure that the community structure analysis differences between SML and SSW were not caused by the MS sampling method, we performed an additional sampling in site R in October 2009 using both PCM and MS (Fig. 5). The DNA yield was lower in samples taken with PCM, and we did not succeed in amplifying the 16S RNA gene from DNA preparations of some of the replicate polycarbonate membranes. However, the similarity between T-RFLP profiles from all samples was $>80 \%$, and the sampling technique did not affect any of the SML and SSW findings significantly.

\section{Metals and DOM}

The presence of bioavailable metals (cadmium, copper, lead and mercury) and cytotoxicity in the water samples taken in the summer of 2007 were detected using recombinant bacterial bioreporters. The only metal detected was cadmium in the SML and SSW samples taken from sampling site R on June 14, 2007. Both SML and SSW contained $100 \mathrm{nM}$ of cadmium (the detection limit of the assay was $70 \mathrm{nM}$ ). No significant cytotoxicity was detected in any of the samples.

The DOC values varied between 318 and $593 \mu \mathrm{mol}$ $\mathrm{l}^{-1}$ (Table 2), with averages of $400 \mu \mathrm{mol} \mathrm{l}^{-1}$ in SSW

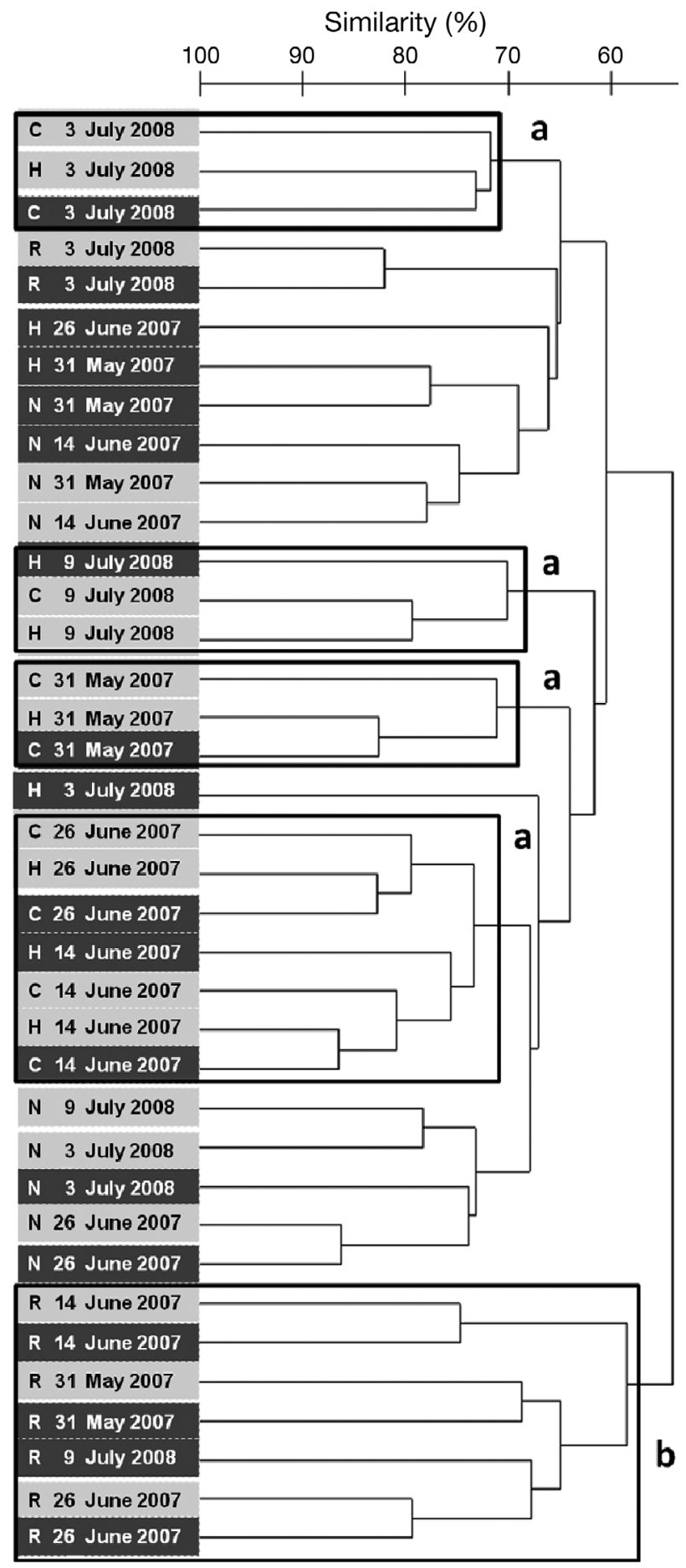

Fig. 4. Dendrogram constructed using hierarchical clustering and results of terminal fragment length polymorphism (T-RFLP) analysis, based on samples taken in summer 2007 and 2008 (sampling dates shown) and on Bray-Curtis similarity index. Sampling sites: C, H, N and R (see Fig. 1); grey boxes: surface-microlayer (SML); black boxes: subsurfacewater (SSW). Results from (a) sites $\mathrm{C}$ and $\mathrm{H}$ clustered close to each other and (b) most of the site R samples formed a separate cluster. Results of HhaI-restricted samples shown in this figure correspond with RsaI results 


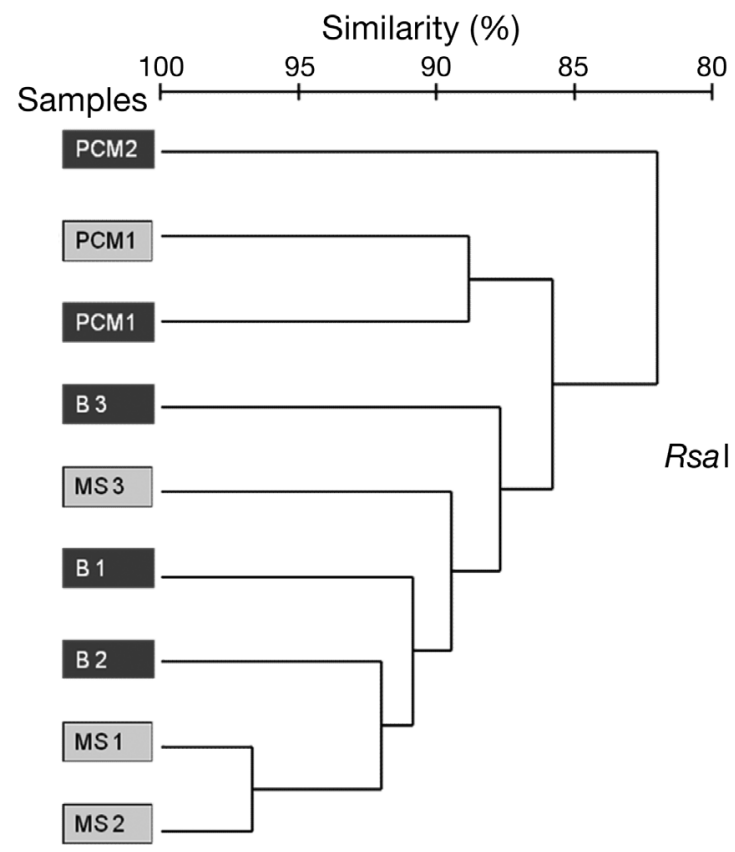

Fig. 5. Comparison of sampling methods. T-RFLP results of polycarbonate membrane (PCM) sampling were compared with metal screen (MS) sampling of the SML (grey boxes) and bottle (B) sampling of SSW (black boxes). The similarity of the communities was measured using the Bray-Curtis algorithm. Picture shows results of restriction enzyme RsaI. Three parallel samples were taken with the same sampling method (1-3). The yield of DNA was not sufficient enough from all of the PCM samples.See Fig. 4 for abbreviations

samples and $392 \mu \mathrm{mol} \mathrm{l}^{-1}$ in SML samples. The samples from the site $\mathrm{R}$ had higher DOC values than the other samples. These results show that there are no significant differences in DOC of SML and SSW samples (1-way ANOVA, $\mathrm{p}>0.1$ ).

HPLC-SEC analysis was performed to see if there were any differences in the quantity, as well as quality of DOM in SML and SSW samples. Further, we wanted to find out whether there is a relation between the bacterial counts and the amount and type of DOM. Typical chromatograms of UV and fluorescence detections are presented in Fig. 6.

The chromatograms of our samples show 2 clearly separated domains. The first domain is comprised of 3 HMW fractions with the apparent molecular weight range of 5000 to $1000 \mathrm{Da}$. The second domain is comprised of the LMW fraction that contains the compounds with apparent molecular weight range of 500 to $150 \mathrm{Da}$ according to the calibration. It is important, however, to remember that the calculated molecular weights are only 'apparent' and cannot be determined precisely, because of the other interactions than size exclusion in the column that cannot be fully
Table 2. Dissolved organic carbon (DOC) values measured in seawater samples. SSW: subsurface water; SML: surface microlayer

\begin{tabular}{|lcc|}
\hline $\begin{array}{l}\text { Station } \\
\text { Date }\end{array}$ & $\begin{array}{c}\text { SSW DOC } \\
\left(\mu \mathrm{mol}^{-1}\right)\end{array}$ & $\begin{array}{c}\text { SML DOC } \\
\left.(\mu \mathrm{mol} \mathrm{l})^{-1}\right)\end{array}$ \\
\hline $\begin{array}{l}\text { Stenskär (C) } \\
\text { June 14, 2007 }\end{array}$ & 363 & 393 \\
June 26, 2007 & 371 & - \\
Stenskär (H) & & \\
May 31, 2007 & 383 & 342 \\
June 14, 2007 & 345 & 351 \\
June 26, 2007 & 350 & 392 \\
Raisio (R) & & 462 \\
May 31, 2007 & - & 556 \\
June 14, 2007 & 593 & - \\
June 26, 2007 & 575 & 354 \\
Nauvo (N) & & 329 \\
May 31, 2007 & 344 & 355 \\
June 14, 2007 & 358 & \\
June 26, 2007 & 318 & \\
\hline
\end{tabular}

eliminated. The LMW fraction was also 'seen' by tryptophan- and tyrosine-like fluorescence detection, suggesting that this fraction might contain proteintype compounds with tryptophan and tyrosine moieties. All samples produced the same fractions, and no additional fractions were observed in any of the chromatograms.

By HPLC-SEC the quantity of organic matter is given by peak area or peak height. In the present study we used the peak areas that correlated better with DOC (Pearson correlation coefficients of $\mathrm{r}=$ 0.83, p $<0.01$ and $r=-0.52, p<0.05$; see Table 3) than the peak heights (Pearson correlation coefficients between DOC-HMW peak heights $\mathrm{r}=0.4, \mathrm{p}$ $<0.05$, and DOC-LMW peak heights $\mathrm{r}=-0.3$, p $<$ $0.05)$. The variations of peak area over the sampling period are presented in Fig. $7 \mathrm{a}, \mathrm{b}$. These figures show that HMW fractions varied to a lesser extent (max. 40\% difference between May 31, 2007 and June 26, $2007 \mathrm{~N}$ samples) than LMW fractions (max. 220\% difference between May 31 and June $26 \mathrm{~N}$ samples). The tyrosine- and tryptophan-like fractions presented the same pattern than LMW fractions and therefore are not presented. Fig. 7b also reveals that there were significant differences between the values of LMW peak areas of the parallel measurements occasionally for all of the sites. Regarding the differences between the DOM of SSW and SML samples during the sampling period, no significant differences were found, neither in the HMW fraction area (1-way ANOVA, p > 0.1) nor the LMW fraction area (1-way ANOVA, p > 


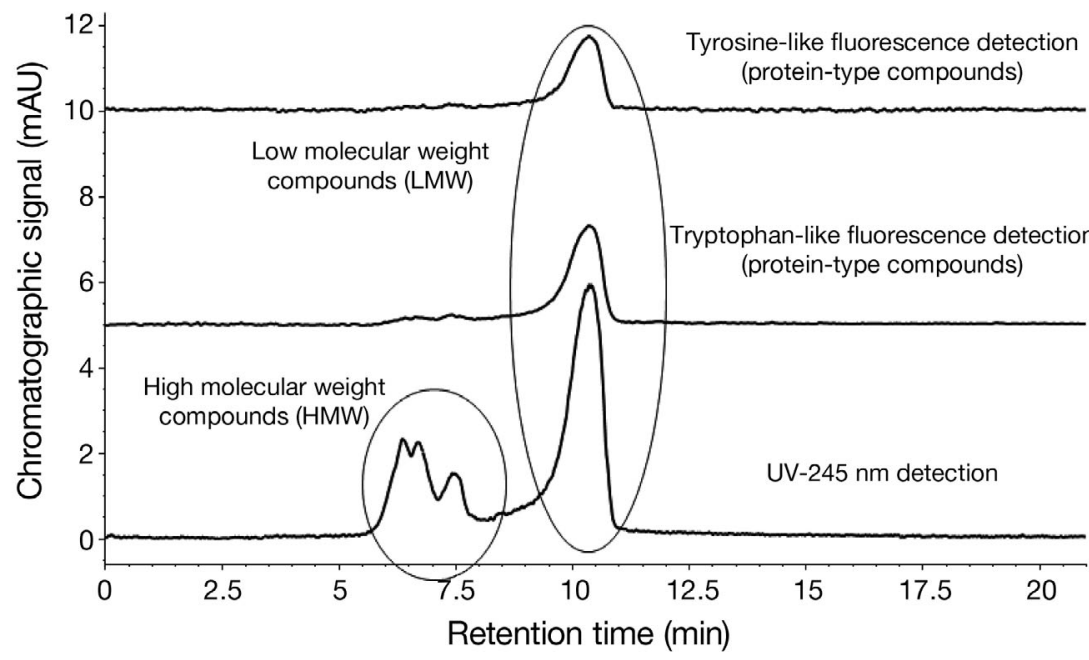

Fig. 6. Typical chromatograms of a seawater sample using UV (ultraviolet) and FLU (fluorescence) detections. mAU: milliAmpere units

0.1), although LMW fractions presented higher variance than HMW fractions (Fig. 7a,b).

Sampling site $\mathrm{R}$ samples presented different patterns in the chromatograms compared to all the other sampling sites, having comparatively the highest HMW and the lowest LMW fraction content (Fig. 7a,b).

Most of the organic matter indicators presented significant correlation with bacterial counts (Table 3). Unexpectedly, LMW fraction and tryptophan- and tyrosine-like fluorescence fraction areas presented negative correlations with bacteria and other organic indicators (Table 3).

\section{DISCUSSION}

SML and SSW bacterial community structures of 4 different sampling sites in the Archipelago Sea of SW Finland were studied. There were in total 5 sampling time points during the summers of 2007 and 2008. In the present study, bacterial community fingerprints revealed differences between SML and corresponding SSW communities in approximately half of the samplings. Significant enrichment of bacteria in the SML was not detected. However, in many of the sampling sites the number of bacteria was slightly higher in SML than in SSW. The analysis of metals and DOM revealed no differences between the chemical composition of SML and SSW.

We observed distinct SML and SSW bacterial communities at many of the sampling sites and time points. The bacterioneuston of the Baltic Sea was studied previously by Stolle et al. (2009, 2010). In their first study (Stolle et al. 2009), differences between SML and SSW bacterial communities were not observed. In the present study, both rotating drum and metal screen were used as sampling methods and single-strand-conformation polymorphism (SSCP) or T-RFLP as a fingerprinting method. Bacterial 16S rDNA fingerprint results were reported based on only one of the sampling sites of their study (Stolle et al. 2009). We had several sampling sites and took samples from sheltered harbour bays, while Stolle et al. (2009) had their sampling site located in a relatively open site in the southern Baltic Sea. However, in their latest study, Stolle et al. (2010) reported some differences between SML and SSW communities and the effect of wind conditions to the succession of bacterial communities in SML. According to that study, the uncoupling of the bacterioneuston and bacterioplankton occurs in calm wind conditions. This finding resembles our observation about variation of bacterial community structure in wind-sheltered bays.

Agogué et al. (2005) studied 2 sampling sites in the Mediterranean Sea. They found differences between SML and SSW bacterial communities using the SSCP

Table 3. Pearson correlation coefficients (r) between organic matter indicators and bacterial counts. DOC: dissolved organic carbon; HMW: high molecular weight; LMW: low molecular weight; Flu: fluorescence. Significance: ${ }^{*} p<0.05$; ${ }^{* *} p<0.01$

\begin{tabular}{|lcccccc|}
\hline Indicator & LMW & HMW & Flu-Tyrosine & Flu-Tryptophan & Total bacteria & Cultured bacteria \\
\hline DOC & $-0.53^{*}$ & $0.83^{* *}$ & -0.14 & -0.38 & $0.79^{* *}$ & $0.83^{* *}$ \\
LMW & 1 & -0.29 & $0.65^{* *}$ & $0.97^{* *}$ & $-0.56^{* *}$ & $-0.53^{*}$ \\
HMW & 1 & -0.2 & -0.09 & $0.46^{*}$ & $0.48^{*}$ \\
Flu-Tyrosine & & & 1 & $0.65^{* *}$ & -0.04 & -0.28 \\
Flu-Tryptophan & & & & 1 & $-0.46^{*}$ & $-0.47^{*}$ \\
Total bacteria & & & & & 1 & $0.52^{*}$ \\
\hline
\end{tabular}



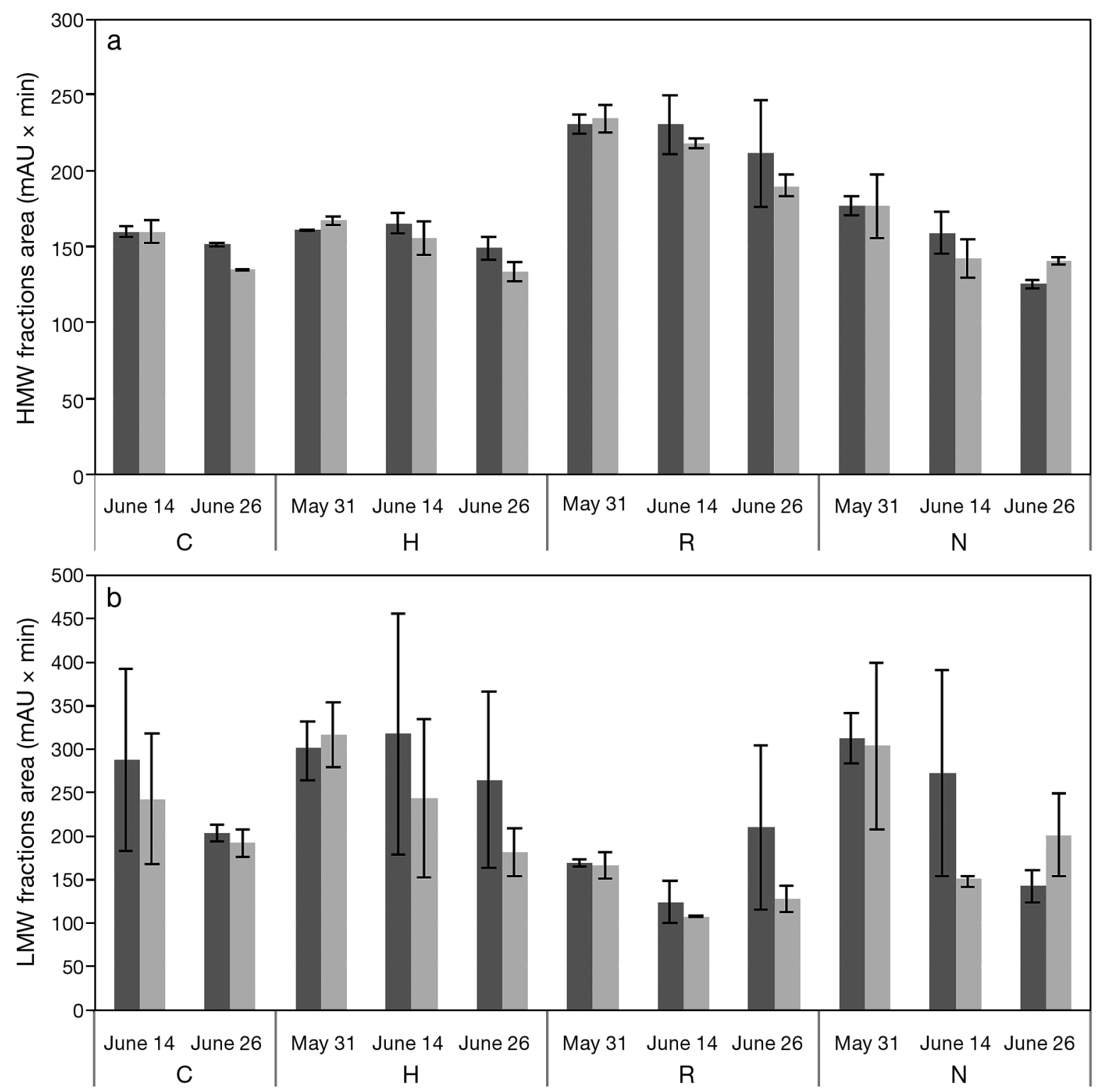

Fig. 7. Variations of the (a) HMW (high molecular weight) fractions area and (b) LMW (low molecular weight) fractions area in surface-microlayer (grey bars) and subsurface-water (black bars) samples in the summer of 2007, as measured by UV-254 nm detection. Averages of 2 replicates with error bars indicating the maximum and minimum values. Sampling sites: $\mathrm{C}, \mathrm{H}, \mathrm{R}$ and N (see Fig. 1)

method, but the results were not reproducible in samplings performed on consecutive days. Overall, their results did not show consistent differences between SML and SSW bacterial species, and the hypothesis was that most of the bacteria inhabiting SML were of planktonic origin. This hypothesis got support from the study of Santos et al. (2009), whose results indicated that bacterioneuston communities are mostly of planktonic origin.

There have been studies where the differences between SML and SSW communities have been more clear and systematic. Franklin et al. (2005) observed that the bacterial diversity was significantly lower in SML than in SSW in the North Sea. Based on clone library construction, they found 9 operational taxonomical units (OTUs) from SML samples compared to a total of 48 OTUs observed in SSW. Cunliffe et al. (2009b) found distinct and consistent bacterial communities in SML in their study. They used TRFLP and denaturing gradient gel electrophoresis (DGGE) to compare the SML and SSW communities. Results of a recent study by Wurl et al. (2010) suggest 
that surfactant enrichment in the SML is stronger in oceanic regions with low productivity than in more productive coastal regions, unlike previously assumed. This could explain variable results in bacterial analysis between SML and SSW from different areas.

Our results indicate that the bacterioneuston in the Archipelago Sea is dynamic and patchy, even in harbour areas, where weather conditions are calm compared to the open sea. However, it is difficult to say to what extent the changes are caused by sampling different moving water masses. Thus, broader spatial and temporal samplings are required to validate this statement. In the light of the results of Wurl et al. (2010), it seems probable that in the present study, the vicinity to the coast had more effect on differences between the SML and SSW samples than the wind conditions, which were $\sim 4 \mathrm{~m} \mathrm{~s}^{-1}$ at the highest. Like Agogué et al. (2005), we observed variability in community profiles at different time points and sampling sites. Differences in SML and SSW communities were observed at some of the sampling points; however, distinct SML communities seemed to be transient. In the present study, there were several sampling sites and time points. This is an advantage, because the SML often seems to be a dynamic environment. Therefore, it can be presumed that our results allow a more accurate observation of the possible variation in the bacterial community appearance opposed to if only a few samples were studied. However, more research with multiple time points should be conducted.

T-RFLP results from autumn 2009 PCM sampling were compared with MS sampling results to observe possible bias due to the sampling method. According to Cunliffe et al. (2009a), a sample taken with a metal screen or a glass plate could be unrepresentative for the SML communities. However, more recently, they found differences between SML and SSW bacterial communities using both MS and polycarbonate membrane (Cunliffe et al. 2009b). Our results showed no significant difference between samples taken with a MS or a polycarbonate filter. However, this result must be considered as suggestive, as the comparison was done only for samples taken from one sampling site. Further, the yield of extracted DNA differed between sampling methods, which made the comparison of samples more difficult.

A modest increase in the amount of bacteria in SML compared to SSW was observed in both culturable and total bacterial counts. Our results show most significant differences in bacterial counts between SML and SSW at the first sampling time point at the end of May 2007. One reason for the higher bacterial counts on June 14, 2007, at sampling site R could be busy boat traffic in the harbour. This possibly increases the bacterial counts, because of waste originating from the boats. In addition, HMW and DOC content of site R sample were the highest. Previous results comparing bacterial counts of SML and SSW have been variable, depending on the sampling area (Kuznetsova et al. 2004, Franklin et al. 2005, Joux et al. 2006). Stolle et al. (2009) did not find differences in bacterial counts between SML and SSW samples in the southern and central Baltic Sea when measured with a flow cytometer.

In the beginning of our study, we hypothesized that if specific communities developed in the SML, the different chemical composition of the SML might be one driver of this process. The enrichment of different toxic and organic compounds in the SML has been shown in many previous studies (Wurl \& Obbard 2004). Thus, we tested whether there was a difference in the quantity or quality of DOM in the SML compared to SSW. In addition, the presence of metals (cadmium, copper, lead and mercury) and cytotoxicity in samples was detected using recombinant bacterial bioreporters. According to our results, the chemical composition of SML was not different from that of the SSW. None of the analysed water samples were cytotoxic, and the concentration of cadmium found in sampling site R on June 14, 2007 was similar in SML and SSW samples.

The DOC levels and chromatograms in the present study resembled those found previously in the Baltic Sea (Stedmon et al. 2007). The HMW fractions separated by size-exclusion chromatography are commonly identified as humic-type fractions in the fresh surface waters (lakes, rivers); these are composed by humic and fulvic acids, which are mainly of terrestrial and, to a lesser extent, of autochthonous origin (Repeta et al. 2002, Leenheer \& Croue 2003). The strong correlation between DOC and HMW found in the present study is in accordance with previous finding that HMW of molecular weight >1000 Da is a significant part of the seawater DOC (Repeta et al. 2002). The strong positive correlations between DOC, HMW fractions and bacterial counts show the inter-relationships between organic matter and bacteria in the marine environments, where bacteria synthesize the precursors of marine DOM or use components of DOM as substrate (Repeta et al. 2002). Higher HMW and DOC content of site R sample is due to the location of this sampling site near the coast, where humus content of the seawater is generally higher due to terrestrial inputs. That was possi- 
bly one reason for the bacterial community structure in site $\mathrm{R}$ to be so different from the other sampling sites (Fig. 5, cluster b).

The LMW fraction was the most variable fraction in our samples. This fraction has earlier been linked with the salinity of seawater ('salt peak') (Stedmon et al. 2007). According to a recent study on well waters, LMW fraction contains nitrate in addition to organic matter and is used to assess the nitrate concentration in the wells (Szabo \& Tuhkanen 2010). Nitrate concentrations, however, are low in the coastal areas of the Baltic Sea, of the order of $\mu g \mathrm{l}^{-1}$ according to Voss et al. (2010), whereas well-water nitrate levels are in $\mathrm{mg} \mathrm{l}^{-1}$ range. Therefore, it is likely that seawater nitrate does not produce a significant increase in the LMW signal. Our experiments showed also that nitrate does not produce tyrosine- and tryptophanlike fluorescence (H. M. Szabo unpubl. data). Nevertheless, in the seawater samples of the present study the LMW fraction was detected by both tryptophanand tyrosine-like detection, suggesting that it contains so-called 'protein-type fluorophores' (Yamashita \& Tanoue 2003) that give the specified fluorescence signals. It was previously found that tyrosine and tryptophan fluorescence intensities of the marine samples correlate with the amount of aromatic amino acids in the marine DOM (Yamashita \& Tanoue 2003). Thus, theoretically the LMW fraction should be at least partly composed by aromatic amino acids (such as tryptophan, tyrosine or phenylalanine) and/or peptides and proteins that contain these aromatic amino acids. However, the negative correlations found between DOC and LMW as well as tyrosine and tryptophan fluorescence (Table 3) seem to support rather the 'salinity-nature' than the 'protein-nature' of this peak.

It has been shown previously that the protein-type fluorescence-unlike the humus-type fluorescence-measured by excitation-emission spectroscopy (EEM) in the Baltic Sea does not change significantly with the relatively small increase of salt concentration (Kowalczuk et al. 2005). Therefore, it is likely that the LMW peak contains the protein-type components of the sample, and it is representative also for salinity. In order to clarify the composition of the LMW fraction of seawater samples, further studies are needed. The significant negative correlations between bacterial counts and LMW tryptophan-like fluorescence were unexpected. Although it is possible that increasing salt concentration causes a decrease of bacterial numbers in the studied samples, we think this is unlikely. Another possibility is that the LMW fraction contains compounds that bac- teria use as substrate. Gaining more understanding about the possible reasons of this finding would require additional studies and measurements. Our results did not show any significant differences between the quantity of DOC in SML and SSW samples. Similar observations or low enrichment factors in the SML have been made in several previous studies on oceanic, coastal and lake waters (Gasparovic et al. 2007, Wurl \& Holmes 2008, Baastrup-Spohr \& Staehr 2009). More significant enrichments of SML were observed previously for a series of organic compounds such as dissolved and particulate fulvic acid (Calace et al. 2007); transparent exopolymer particles (polysaccharides, proteins and lipids) (Wurl \& Holmes 2008); and a range of organic pollutants (Wurl \& Obbard 2004). Therefore we expected significant differences between the organic fractions eluted through HPLC-SEC of SML and SSW samples. The reason that there were no differences might be that the HPLC-SEC is not sensitive enough to detect these differences. This method is useful for analyzing up to tens of $\mathrm{mg} \mathrm{l}^{-1}$ amounts of global organic matter. Lower amounts of particular organic compounds cannot be detected. Additionally, as discussed earlier in this section, there is uncertainty related to the composition and detection of LMW peak containing the protein-type and other LMW compounds, making the detection of the differences even more difficult.

DOC and HPLC-SEC measure the global organic matter content (including: humic matter, proteins, sugars and extracellular organic polymers). The SEC column separates the organic mixture into fractions, and multiple detection allows making differentiation between the mainly humic fractions (UV-254 detection) and protein-type fractions (LMW seen by protein-type fluorescence detection). The exact composition of the fractions is, however, unknown. It is possible that, in spite of the equal global organic content, the composition of the fractions from SSW and SML samples is different, affecting the bacterial composition.

Using DOC and HPLC-SEC for characterization of marine DOM, no significant differences between SSW and SML samples were detected in the present study. According to previous research (Kuznetsova et al. 2004, Reinthaler et al. 2008, Wurl et al. 2010,) there seems to be enrichment of DOC and surfactants in the SML, particularly at high wind speeds. Our sampling time points were chosen based on calm weather conditions, as we assumed the SML bacterial communities to be most stable at low wind speeds (Table 1). 
In the present study, the differences between bacterial communities in SML and SSW do not seem to be due to metal stress, cytotoxicity, or concentrations of organic matter. We hypothesize that exposure to UV radiation may be one factor driving the differentiation of bacterioneuston community. However, more research is needed to find out which environmental factors are essential in the forming of separate bacterioneuston communities in the Baltic Sea causing differing bacterial communities in the Baltic Sea SML and SSW.

\section{CONCLUSIONS}

In the present study, metal concentrations did not differ substantially between the Archipelago Sea SML compared to the underlying water. With the methods used to characterize DOM, such as DOC determination and HPLC-SEC, no significant differences in organic matter content were found either. However, differences between bacterial communities of SML and SSW were observed. Approximately half of the SML and SSW sampling pairs compared were considered to represent diverging communities, and in some cases more similarity was observed between bacterial community profiles from different sampling sites than between the SML and the SSW of the same site. Since no temporal trends were obvious, our results suggest that although bacterial communities in the SML of the Archipelago Sea differ to some extent from the ones living in SSW, SML is a dynamic environment where bacterial communities possibly develop originally from bacterioplankton and change over time. Further studies on the stability of bacterial communities of SML and their role in the ecosystem of the Baltic Sea need to be conducted.

Acknowledgements. We thank Dr. F. Joux for guiding us to the sampling of SML. We also thank L. Pitkänen for critical reading of the article and $\mathrm{T}$. Lilley for language revision. Financial support was provided by the Maj and Tor Nessling Foundation and the Pirkanmaa Regional Fund of Finnish Cultural Foundation.

\section{LITERATURE CITED}

Abdo Z, Schuette UME, Bent SJ, Williams CJ, Forney LJ, Joyce P (2006) Statistical methods for characterizing diversity of microbial communities by analysis of terminal restriction fragment length polymorphisms of $16 \mathrm{~S}$ rRNA genes. Environ Microbiol 8:929-938

Agogué H, Casamayor EO, Joux F, Obernosterer I and others (2004) Comparison of samplers for the biological characterization of the sea surface microlayer. Limnol Oceanogr Methods 2:213-225

Agogué H, Casamayor EO, Bourrain M, Obernosterer I, Joux F, Herndl GJ, Lebaron P (2005) A survey on bacteria inhabiting the sea surface microlayer of coastal ecosystems. FEMS Microbiol Ecol 54:269-280

Avaniss-Aghajani E, Jones K, Chapman D, Brunk C (1994) A molecular technique for identification of bacteria using small-subunit ribosomal-RNA sequences. Biotechniques 17:144

Baastrup-Spohr L, Staehr PA (2009) Surface microlayers on temperate lowland lakes. Hydrobiologia 625:43-59

Bell CR, Albright LJ (1982) Bacteriological investigation of the neuston and plankton in the Fraser River estuarine, British Columbia. Estuar Coast Shelf Sci 15:385-394

> Bezdek HF, Carlucci AF (1972) Surface concentration of marine bacteria. Limnol Oceanogr 17:566

Calace N, Catrambone T, Petronio BM, Pietroletti M (2007) Fulvic acid in microlayer waters of the Gerlache Inlet Sea (Antarctica): their distribution in dissolved and particulate phases. Water Res 41:152-158

Culman SW, Bukowski R, Gauch HG, Cadillo-Quiroz H, Buckley DH (2009) T-REX: software for the processing and analysis of T-RFLP data. BMC Bioinformatics 10:171 doi:10.1186/1471-2105-10-171

Cunliffe M, Murrell JC (2009) The sea-surface microlayer is a gelatinous biofilm. ISME J 3:1001-1003

> Cunliffe M, Harrison E, Salter M, Schäfer H, Upstill-Goddard RC, Murrell JC (2009a) Comparison and validation of sampling strategies for the molecular microbial analysis of surface microlayers. Aquat Microb Ecol 57:69-77

> Cunliffe M, Whiteley AS, Newbold L, Oliver A, Schäfer H, Murrell JC (2009b) Comparison of bacterioneuston and bacterioplankton dynamics during a phytoplankton bloom in a fjord mesocosm. Appl Environ Microbiol 75: 7173-7181

> Cunliffe M, Upstill-Goddard RC, Murrell JC (2011) Microbiology of aquatic surface microlayers. FEMS Microbiol Rev 35:233-246

> Dahlgren K, Andersson A, Larsson U, Hajdu S, Båmstedt U (2010) Planktonic production and carbon transfer efficiency along a north-south gradient in the Baltic Sea. Mar Ecol Prog Ser 409:77-94

Daumas RA, Laborde PL, Marty JC, Saliot A (1976) Influence of sampling method on chemical composition of water surface film. Limnol Oceanogr 21:319-326

> Franklin MP, McDonald IR, Bourne DG, Owens NJP, UpstillGoddard RC, Murrell JC (2005) Bacterial diversity in the bacterioneuston (sea surface microlayer): the bacterioneuston through the looking glass. Environ Microbiol 7: 723-736

- Garrett WD (1965) Collection of slick-forming materials from sea surface. Limnol Oceanogr 10:602-605

Gasparovic B, Plavsic M, Cosovic B, Saliot A (2007) Organic matter characterization in the sea surface microlayers in the subarctic Norwegian fjords region. Mar Chem 105:1-14

Gast V, Gocke K (1988) Vertical-distribution of number, biomass and size-class spectrum of bacteria in relation to oxic anoxic conditions in the central Baltic Sea. Mar Ecol Prog Ser 45:179-186

> Ghiglione JF, Larcher M, Lebaron P (2005) Spatial and temporal scales of variation in bacterioplankton community structure in the NW Mediterranean Sea. Aquat Microb Ecol 40:229-240

Hardy JT (1982) The sea-surface microlayer — biology, chem- 
istry and anthropogenic enrichment. Prog Oceanogr 11: 307-328

> Heinanen AP (1991) Bacterial numbers, biomass and productivity in the Baltic Sea-a cruise study. Mar Ecol Prog Ser 70:283-290

Hermansson M, Jones GW, Kjelleberg S (1987) Frequency of antibiotic and heavy-metal resistance, pigmentation and plasmids in bacteria of the marine air-water interface. Appl Environ Microbiol 53:2338-2342

> Holmfeldt K, Dziallas C, Titelman J, Pohlmann K, Grossart HP, Riemann L (2009) Diversity and abundance of freshwater Actinobacteria along environmental gradients in the brackish northern Baltic Sea. Environ Microbiol 11: 2042-2054

> Ivask A, Rolova T, Kahru A (2009) A suite of recombinant luminescent bacterial strains for the quantification of bioavailable heavy metals and toxicity testing. BMC Biotechnol 9:41 doi:10.1186/1472-6750-9-41

Joux F, Agogué H, Obernosterer I, Dupuy C, Reinthaler T, Herndl GJ, Lebaron P (2006) Microbial community structure in the sea surface microlayer at two contrasting coastal sites in the northwestern Mediterranean Sea. Aquat Microb Ecol 42:91-104

Koskinen K, Hultman J, Paulin L, Auvinen P, Kankaanpaa H (2011) Spatially differing bacterial communities in water columns of the northern Baltic Sea. FEMS Microbiol Ecol 75:99-110

> Kowalczuk P, Ston-Egiert J, Cooper WJ, Whitehead RF, Durako MJ (2005) Characterization of chromophoric dissolved organic matter (CDOM) in the Baltic Sea by excitation emission matrix fluorescence spectroscopy. Mar Chem 96:273-292

$>$ Kuznetsova M, Lee C, Aller J, Frew N (2004) Enrichment of amino acids in the sea surface microlayer at coastal and open ocean sites in the North Atlantic Ocean. Limnol Oceanogr 49:1605-1619

LaRossa RA, Smulski DR, Vandyk TK (1995) Interaction of lead, nitrate and cadmium chloride with Escherichia coli K-12 and Salmonella typhimurium global regulatory mutants. J Ind Microbiol 14:252-258

> Leenheer JA, Croue JP (2003) Characterizing aquatic dissolved organic matter. Environ Sci Technol 37: 18A-26A

Liss PS, Duce RA (eds) (1997) The sea surface and global change, Cambridge University Press, Cambridge

Liu WT, Marsh TL, Cheng H, Forney LJ (1997) Characterization of microbial diversity by determining terminal restriction fragment length polymorphisms of genes encoding 16S rRNA. Appl Environ Microbiol 63:4516-4522

Maki JS (2003) Neuston microbiology: life at the air-water interface. Encyclopedia of Environmental Microbiology. John Wiley and Sons, New York, NY

Naumann E (1917) Beiträge zur Kenntnis des Teichnannoplanktons. II. Über das Neuston des Süsswassers. Biolog Zentralblatt 37:98-106

Norkrans B (1980) Surface microlayers in aquatic environments. Adv Microb Ecol 4:51-85

Pandey J, Ganesan K, Jain RK (2007) Variations in T-RFLP profiles with differing chemistries of fluorescent dyes used for labeling the PCR primers. J Microbiol Methods 68:633-638
Reinthaler T, Sintes E, Herndl GJ (2008) Dissolved organic matter and bacterial production and respiration in the sea-surface microlayer of the open Atlantic and the western Mediterranean Sea. Limnol Oceanogr 53:122-136

> Repeta DJ, Quan TM, Aluwihare LI, Accardi AM (2002) Chemical characterization of high molecular weight dissolved organic matter in fresh and marine waters. Geochim Cosmochim Acta 66:955-962

> Santos AL, Mendes C, Gomes NCM, Henriques I, Correia A, Almeida A, Cunha A (2009) Short-term variability of abundance, diversity and activity of estuarine bacterioneuston and bacterioplankton. J Plankton Res 31: 1545-1555

> Smalla K, Oros-Sichler M, Milling A, Heuer H and others (2007) Bacterial diversity of soils assessed by DGGE, TRFLP and SSCP fingerprints of PCR-amplified 16S rRNA gene fragments: Do the different methods provide similar results? J Microbiol Methods 69:470-479

Smith CJ, Danilowicz BS, Clear AK, Costello FJ, Wilson B, Meijer WG (2005) T-Align, a web-based tool for comparison of multiple terminal restriction fragment length polymorphism profiles. FEMS Microbiol Ecol 54:375-380

> Stedmon CA, Markager S, Tranvik L, Kronberg L, Slatis T, Martinsen W (2007) Photochemical production of ammonium and transformation of dissolved organic matter in the Baltic Sea. Mar Chem 104:227-240

> Stolle C, Nagel K, Labrenz M, Jürgens K (2009) Bacterial activity in the sea-surface microlayer: in situ investigations in the Baltic Sea and the influence of sampling devices. Aquat Microb Ecol 58:67-78

Stolle C, Nagel K, Labrenz M, Jürgens K (2010) Succession of the sea surface microlayer in the coastal Baltic Sea under naturally and experimentally induced low-wind conditions. Biogeosciences 7:2975-2988

Szabo HM, Tuhkanen T (2010) The application of HPLCSEC for the simultaneous characterization of NOM and nitrate in well waters. Chemosphere 80:779-786

> Tauriainen S, Karp M, Chang W, Virta M (1998) Luminescent bacterial sensor for cadmium and lead. Biosens Bioelectron 13:931-938

Vaatanen P (1980) Microbiological parameters for differentation between coastal and open waters in the northern Baltic proper and the Gulf of Finland. J Appl Bacteriol 49:455-462

Vaatanen P (1982) Effects of fresh-water outflows on microbial populations in the Tvärminne Archipelago, Southern Finland. Holarct Ecol 5:61-66

Voss M, Deutsch B, Liskow I, Pastuszak M, Schulte U, Sitek S (2010) Nitrogen retention in the Szczecin Lagoon, Baltic Sea. Isotopes Environ Health Stud, 46:355-369

> Wurl O, Holmes M (2008) The gelatinous nature of the seasurface microlayer. Mar Chem 110:89-97

> Wurl O, Obbard JP (2004) A review of pollutants in the seasurface microlayer (SML): a unique habitat for marine organisms. Mar Pollut Bull 48:1016-1030

> Wurl O, Wurl E, Miller L, Johnson K, Vagle S (2010) Formation and distribution of sea-surface microlayers. Biogeosciences Discuss 7:5719-5755

Yamashita Y, Tanoue E (2003) Chemical characterization of protein-like fluorophores in DOM in relation to aromatic amino acids. Mar Chem 82:255-271 